The Canadian Journal of Higher Education, Vol. XXIII-1, 1993

La revue canadienne d'enseignement supérieur, Vol. XXIII-1, 1993

\title{
Unequal Returns: Gender Differences in Initial Employment Among University Graduates*
}

\section{KAREN D. HUGHESA \& GRAHAM S. LOWE ${ }^{\dagger}$}

\begin{abstract}
This paper examines how socio-demographic, educational, work attitude, and labour market characteristics contribute to gender differences in the earnings and promotion opportunities of 1985 university graduates employed full-time one year after graduating. Even after accounting for the effects of faculty of enrolment, gender differences in initial employment outcomes are attributable to gender-segregated labour market structures, union and professional association membership, and specific job conditions. Thus, men and women graduating from the same faculty and university translate credentials into different kinds of employment futures. Interestingly, wanting a job with good promotion opportunities at the time of graduation increased the chance of finding such a job, regardless of sex. This paper concludes by exploring the theoretical and policy implications of these findings.
\end{abstract}

\section{Résumé}

Cet article étudie l'impact selon le sexe des caractéristiques sociodémographiques, de l'éducation, des attitudes face au travail, et du marché de l'emploi en regard des différences de revenus et des perspectives de promotion

-Funding for this study was provided by Alberta Carcer Development and Employment, and the Social Sciences and Humanities Research Council. We wish to thank Harvey Krahn, John Myles, Barry Scholnick, and the three anonymous reviewers for helpful comments on earlier drafts of this paper. We also are grateful to Guy Germain for translating the abstract into French

$\Delta$ University of Cambridge

†University of Alberta, Department of Sociology 
des diplômés universitaires de 1985, un an après leur diplômation. Même en tenant compte des différences disciplinaires, on observe que les écarts de revenus sont attribuables aux structures du marché de l'emploi qui s'avèrent différentes selon le sexe, à l'appartenance ou non à des associations syndicales et professionnelles, et enfin, aux conditions spécifiques à l'emploi. En conséquence, les hommes et les femmes qui diplôment d'un même programme et d'une même université ne disposent pas des mêmes perspectives d'emploi futures même s'ils possèdent le même diplôme. Il est aussi intéressant de noter que les diplômés à la recherche d'un emploi qui offre des possibilités d'avancement dans la carrière au moment de l'obtention du diplôme, augmentent leur chance d'obtenir un tel emploi, indépendamment du sexe du candidat. L'article conclut en explorant les implications théoriques et pratiques de cette étude.

\section{Introduction}

The 1980s were a decade of socioeconomic paradoxes for Canadian women. More females than males enrolled in postsecondary educational programs; and since 1982 , women have received the majority of undergraduate degrees (Gilbert \& Guppy, 1988, p. 165). Yet gender segregation persists in universities: male undergraduates are concentrated in engineering and applied sciences; female undergraduates are clustered in nursing, household sciences, and elementary-primary education (Mori \& Burke, 1989). True, some male-dominated fields such as pharmacy (and, increasingly, medicine) are undergoing feminization (Marshall 1989); but this is overshadowed by women's growing concentration in education, arts disciplines, and other female dominated fields of study (Gilbert \& Guppy, 1988).

Within the labour force, the male-female wage gap is less among university graduates than among non-university educated workers (Gunderson, 1989, p. 52). Nonetheless, women who entered the labour market with university degrees in the 1980s earned less than males with similar credentials in virtually all occupations (Wannell, 1990). Despite employment equity policies and rapid increases in the number of women entering management occupations, relatively few have moved up into upper-middle and senior management positions in either the public or private sector (Peitchinis, 1989).

Against the backdrop of these trends, this paper examines sources of gender inequality in two key labour market outcomes - income and promotion opportunities - in a sample of 1985 university graduates employed full-time one year after graduation. Our analysis of the linkages between postsecondary educational credentials and the labour market addresses the following questions: 
1) How is human capital incorporated into the labour market differently for men and women upon graduation from university? 2) How are prior gender differences in education, particularly faculty of study, incorporated into gender-segregated occupational structures? 3) Are there gender differences in occupational aspirations and work orientations which may influence initial entry-level employment?

\section{Theoretical Issues}

Sociological research has only partially illuminated these question. The complexity of gender stratification - based on mutually reinforcing roles played by the family, educational institutions, work organizations, and societal values encourages competing paradigms (Brinton, 1988, p. 300). Indeed, the lack of consensus about the causes and consequences of occupational gender segregation reflects the difficulty of bridging individualistic (micro) and structural (macro) levels of analysis.

The major individualistic explanations of variations in employment outcomes are human capital theory, derived from neoclassical economics, and sociological models of status attainment. These perspectives emphasize the importance of individuals' ascribed and achieved characteristics in occupational attainment and rewards (Coverman, 1988). Human capital and status attainment theories would thus view these occupational trends as evidence of women reaping greater labour market returns as a result of their increased investments in human capital (Jacobs, 1989, p. 171).

Wannell's (1990) study of the impact of a variety of human capital characteristics on the earnings of 1982 Canadian male and female university graduates exemplifies the individualistic approach. Using the 1982 National Graduate Survey and the Follow-up of 1982 Graduates Survey, he finds that, despite having the same educational credentials, female university graduates earned an average of $88 \%$ of males graduates' earnings in 1984, with this ratio falling to $82 \%$ by 1987 . Gender differences in the field of study exerted the strongest influence on the earnings gap.

Wannell's (1990) human capital perspective limits his research focus in several ways. He emphasizes graduates' characteristics (e.g., age, language, marital and family status, prior work experience, degree level, field of study, etc.) because they influence labour supply; but he does not consider labour market factors affecting the demand for female and male graduates. Another limitation is that Wannell's only dependent variable is earnings, despite the importance of other job rewards in the overall pattern of labour market inequity. Certainly human capital influences one's life chances. To this extent, 
Wannell's (1990) multivariate analysis does account for 33\% of the earnings gap in both study years. But also important to consider are structural factors which shape the demand for labour. Structural models of segmented labour markets or economic dualism (Baron \& Bielby, 1980) highlight the role of labour market and industry structures in the distribution of life chances (Kalleberg \& Berg, 1987, pp. 26-28). In contrast to the individualistic theories above, structural theories argue that long-term trends in the wage gap and occupational gender segregation indicate entrenched barriers (Jacobs, 1989, p. 1971). For example, a structural analysis of graduates' initial labour market outcomes would include measures such as the gender-segregated occupational structure being entered, union and professional association membership, and intrinsic and extrinsic job rewards which reflect the organization of work within firms.

To achieve a better understanding of how a university degree confers advantages differently for men and women in the early stage of their careers, we must look beyond any single theoretical perspective. Not surprisingly, there is growing recognition of the need to combine structural and individual factors in explanations of labour market inequalities. Baron and Bielby (1980) argue that structural models reject status attainment theory; yet they fail to explain how structures actually influence occupational attainment. Similarly, status attainment researchers acknowledge the need to pay greater attention to the relative roles of both individual and structural factors, including labour market factors such as unemployment, rising job competition, and the declining value of postsecondary education (Knottnerus, 1987; Harvey \& Kalwa, 1983).

But combining elements from human capital theory and segmentation models still produces an incomplete picture. Discussions of gender inequality in employment must also be informed by research on gender role socialization (MacKie, 1987; Ireson \& Gill, 1988), and by feminist critiques of both structural and individualistic models (Beechey, 1988; Dex, 1985, ch. 5; Gaskell, 1987). Furthermore, neither model adequately accounts for the effects of work-related attitudes, even though it is widely assumed that gender socialization influences work behaviour. Human capital theorists (Becker, 1985) claim that women have lower employment commitment than men, while sociologists argue that such differences are diminishing (Lorence, 1987; Moen \& Smith, 1986; Dex, 1988). Women's lower occupational attainment and rewards often are attributed to their lower educational and occupational aspirations, which in turn stem from socialization for femininity (Ireson \& Gill, 1988, p. 132; also see Porter et al., 1982; Turrittin et al., 1983; Gaskell, 1987). Generally, we know little about the 
relationship between women's work attitudes and their employment situations (Purcell, 1989, p. 158).

Finally, both individualistic and structural perspectives can be faulted for not conceptualizing the life cycle into their analysis. Major life transitions, such as the transition of young people from university into the labour force, are central to any thorough explanation of how gender inequalities are perpetrated within and across generations. We need more insights about how gender-specific employment patterns develop over the life course (Blossfeld, 1987, p. 90).

In sum, the complex patterns of continuity and change in women's employment demand that we integrate elements from human capital, status attainment, structural, and gender socialization traditions. In this paper we examine sociodemographic, education, work attitude, and labour market characteristics which may differentially affect earnings and promotion opportunities of male and female university graduates. Far from attempting to propose a new theoretical synthesis, we take a modest first step in this direction by integrating both micro and macro factors into a single explanatory framework in order to address our research questions.

\section{Data and Methods}

Our data come from a panel study of 1985 high school and university graduates in three Canadian cities, Edmonton, Toronto, and Sudbury (for details, see Krahn, 1988). We examine the university sub-sample, which consists of a one in three systematic sample of all graduates from five faculties (Arts, Science, Business, Education, and Engineering) at three universities (Alberta, Toronto, Laurentian) in the spring of 1985 . Respondents were mailed a questionnaire in May 1985 (T1), then followed up with another questionnaire in 1986 (T2). Our focus in this paper is on labour market outcomes during the first twelve months after graduation. Attrition bias was minimal, given that $82 \%$ of those who provided contact information at $\mathrm{T} 1$ also responded at $\mathrm{T} 2$. We examine only those university graduates who reported holding a full-time job at $\mathrm{T} 2$ and who had left the educational system. The total sub-sample size is 529 , of which 301 or $57 \%$ are female.

\section{Socio-Demographic and Educational Characteristics}

Male and female respondents are similar socio-demographically. The mean age at the time of graduation (T1) was 23 years for both sexes. A slightly higher proportion of females were married at $\mathrm{T} 1$ (about $17 \%$ compared with $12 \%$ of the males); however, only about $3 \%$ of females and males reported raising children at Tl. About $15 \%$ and $28 \%$ of all respondents' mothers and fathers, respectively have a university degree. 
Table 1

Faculty of Study, University Graduates Employed Full-Time One Year After Graduation, by Gender '

\begin{tabular}{lcc} 
& Female & Male \\
Arts & $30.9 \%$ & $17.5 \%$ \\
Business & 16.9 & 23.7 \\
Education & 37.2 & 9.6 \\
Engineering & 2.3 & 30.7 \\
Science & 12.6 & 18.4 \\
\cline { 2 - 3 } & $100.0 \%$ & $100.0 \%$ \\
(n) & $(301)$ & $(228)$ \\
\hline Includes only those respondents who reported holding a lull-time job at the time of the \\
\hline
\end{tabular}

In terms of educational characteristics, males and females had almost identical final year grades ( $71 \%$ and $70 \%$, respectively); however, Table 1 documents major gender differences in faculty of study consistent with national trends (Mori \& Burke, 1989). Females are highly concentrated in Arts and Education faculties. Males are more likely to graduate with degrees in Engineering, Business, or Science.

\section{Work Attitudes}

It is also important to consider respondents' occupational aspirations and work orientations at the time of graduation, for these could reflect gender differences in socialization which influence early career choices (see Table 2). As measured by the revised Blishen Scale ${ }^{1}$ of occupational status (Blishen et al., 1987), women had significantly lower occupational aspirations than their male counterparts at the time of graduation, although the scale difference is not great (Blishen scores of 63.5 and 67.7).2

Table 2 also reports four measures of work orientations (mean scores on five-point Likert scales). There are not statistically significant female-male differences on two work values: the importance of finding work that "pays well" after leaving university and the belief that "having a job makes me feel I' $m$ doing something useful with my life;" however, women were significantly less likely than men to believe that it was important for them to find a job "with good chances for promotion and advancement" upon graduating, although the actual difference in small. In contrast, male graduates were significantly more 
Table 2

Occupational Aspirations and Work Orientations at Time of Graduation, University Graduates Employed Full-time One Year After Graduation, by Gender $^{1}$

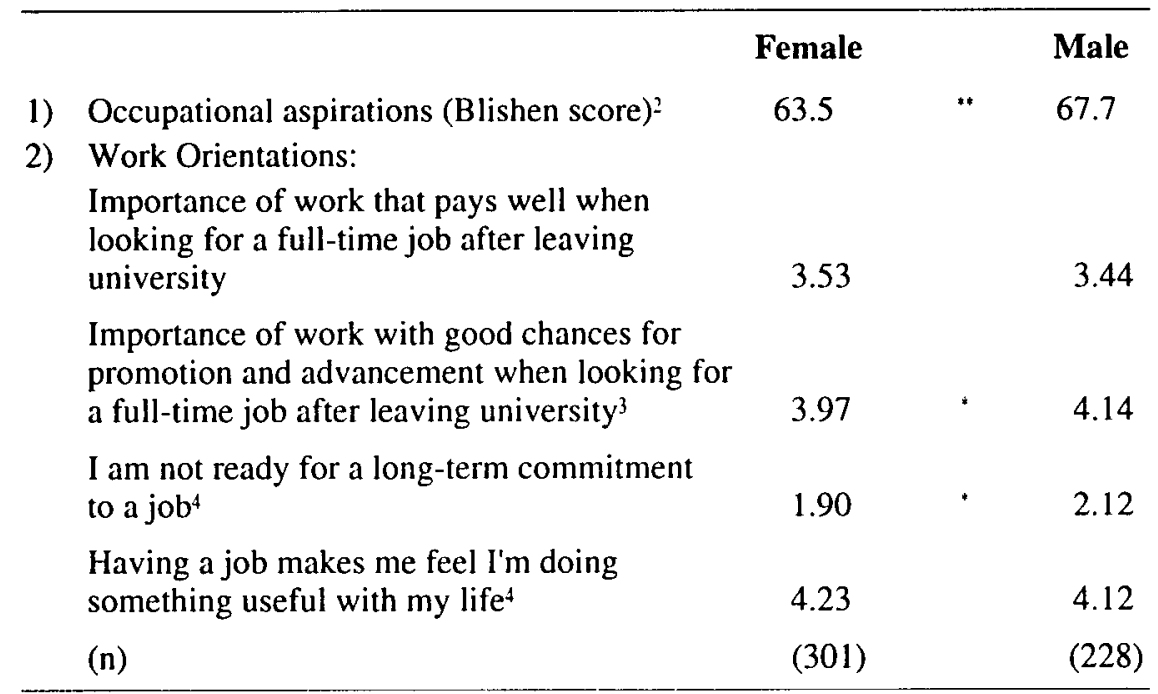

1 Includes only those respondents who reported holding a full-time job at the time of the 1985 followup survey $(n=529)$.

2 Occupational status scores from Blishen et al. (1987) measured at time of graduation, Spring 1985.

3 Mean scores on a live-point scale where 1 is "not important at all" and 5 is "very important." Actual statement wordings are as shown.

4 Mean scores on a five-point scale where 1 is "strongly disagree" and 5 is "strongly agree." Actual statement wordings are as shown.

* Difference between females and males is signilicant at $p<.05$

**Difference between females and males is significant at $p<.01$

likely to agree that "I am not ready for a long-term commitment to a job." Again, the actual difference is small yet significant.

\section{Labour Market Outcomes One Year After Graduation: Descriptive Results}

Graduates' labour market experiences prior to and immediately following graduation deserve brief comment. Some $65 \%$ of females and $57 \%$ of males were employed during the last year of university, although this difference is not statistically significant. In the year after graduation, the typical graduate of either sex was employed full-time for an average of 8 months; however, $19 \%$ of 
Table 3

Labour Market Outcomes, University Graduates Employed Full-time One Year After Graduation, by Gender ${ }^{i}$

Female

Male

a) Occupation one year after graduation:

Managerial

Science/Engineering

Social Sciences

Teaching

Medicine

Artistic/Recreation

Clerical

Sales

Service

Blue-collar

Total

b) Current job conditions:

Mean hours worked per week

Mean weekly take-home pay

Percent union member ${ }^{2}$

Percent professional association member ${ }^{2}$

$\begin{array}{ccc}40.3 & * * & 42.9 \\ \$ 332.52 & * * & \$ 400.86 \\ 24.7 & * * & 13.2 \\ 35.7 & & 44.1\end{array}$

c) Respondent's description of job3:

The work is interesting

I have freedom to decide what I do in my job

The job gives me a feeling of accomplishment

The job lets me use my skills and abilities

3.90

The fringe benefits are good

3.90

The chances for promotion are good

The job security is good

1 Includes only those respondents who reported holding a full-time job at the time of the 1985 followup survey $(n=529)$.

2 Fifteen repondents $(2.8 \%)$ who reported belonging to both a union and a professional association are recorded as members of both.

3 Actual statement wordings are as shown. Agreement is measured on a five-point scale where 1 is "strongly disagree" and 5 is "strongly agree."

* Difference between females and males is signilicant at $p<.05$

** Difference between females and males is significant at $p<.01$

$* * *$ Difference between females and males is significant at $p<.001$ 
women compared with $11 \%$ of men $(\mathrm{p}<.05)$ participated in government-sponsored job creation programs in the year following graduation. This difference reflects the high proportion of females among Education graduates and the fact that the Alberta government had a teaching intern program during 1985-86.

Table 3 documents the occupations of graduates, as well as basic working conditions, after one year in the labour force. Females were concentrated in teaching, clerical work, and management. By comparison, men were over-represented in science and engineering occupations and in management. Almost no women were in blue-collar occupations, whereas about $7 \%$ of males held such jobs.

These gender-segregated employment patterns mirror those found in the Canadian labour force (Krahn \& Lowe, 1993, pp. 73-75). At the same time, we must recognize the effect of faculty of study on occupational attainment. Among the five faculties we sampled, women were over-represented in Arts and Education faculties (Table 1); hence the high proportion of female graduates who had entered teaching occupations and clerical work (still an occupational destination for female Arts graduates)(cf. Devereaux \& Rechnitzer, 1978; Krahn \& Lowe, 1990). In short, occupational gender segregation within our sample of university graduates resulted partly from prior gender differences in choice of faculty.

Examining specific job conditions, we find that female graduates, in comparison with males, worked fewer hours on average each week. Although statistically significant, this difference amounts to less than 3 hours weekly. Of far greater importance is the $\$ 68$ difference in weekly take-home pay (after taxes and deductions). In other words, women earned $83 \%$ of the net weekly salary of their male counterparts after one year in the labour market. The gender wage gap in our sample is fairly consistent with Wannell's (1990) finding of an 87\% gap in gross annual salaries received by 1982 university graduates who were employed full-time in 1984.

One in four female graduates, in contrast to fewer than one in eight males, belonged to a union. The large number of female Education faculty graduates accounts for the higher female union membership. The impact of union membership on female earnings probably is less substantial than for male engineering and business graduates who belong to professional associations.

Table 3 also reports respondents' descriptions of specific intrinsic and extrinsic job characteristics, indicating the overall quality of employment. Only one of the five - chances for promotion - shows a statistically significant gender difference, with males reporting greater opportunities in this respect. 
The mean scores for the other four measures indicate that the jobs males had obtained one year after graduation offered only minimal advantages in terms of decision-making freedom, use of skills and abilities, fringe benefits, and job security.

\section{Explaining Gender Differences in Earnings and Promotion Opportunities: Regression Results}

In many respects, the male and female university graduates in our study have similar socio-demographic characteristics, educational attainment, and final year grades. We have identified, however, small yet statistically significant differences in occupational aspirations and, to some extent, work orientations. Even more central are the distinct gender patterns regarding faculty of study, which we have suggested are reflected in the occupations obtained one year after graduation. As in the Canadian labour force, occupational gender segregation is clearly evident. Moreover, men and women have disparate work hours and rates of participation in key labour market institutions (e.g., unions, government job programs). But most crucially, within one year of graduating, men have net earnings $17 \%$ greater than women and have better self-assessed prospects for promotion.

These bivariate results raise questions about the relative impact of key socio-demographic, educational, work attitude, and labour market factors on employment outcomes one year after graduation. The multivariate results reported in Tables 4 and 5 address these questions by examining the determinants of earnings and promotion opportunities. Within one year of graduating from university, men do better than women in both these respects. This is not surprising. Indeed, recent pay and employment equity policies are aimed at the barriers women historically have encountered to many jobs with good pay and advancement opportunities.

As in the previous tables, the multivariate analyses include only respondents with full-time jobs at T2. The equations presented in Tables 4 and 5 are reduced-form. That is, stepwise regression using all independent variables identified those with significant net effects at the .05 level for males and females separately. ${ }^{3}$ In order to determine how the same variables affect men and women, equations were re-estimated with all variables which had shown significant effects for either sex. Both tables include separate equations for men and women.

The following independent variables - which are loosely categorized as individualistic and structural in light of our earlier theoretical discussion - 
were included in the full regression equations predicting income and promotion opportunities:

\section{Individualistic:}

Socio-demographic characteristics: Respondent's age at time of graduation (in years); sex $(1=$ male); marital status at $\mathrm{T} 1$ $(0=$ single, separated, divorced; $1=$ married); raising own or partner/spouse's children at T2 (1=yes).

Education: Dummy variables for the five faculties in our sample with Arts as the reference category; final year grades (percent).

City: Dummy variables for the cities in the sample with Edmonton as the reference category.

Occupational aspirations: Blishen score of occupation aspired to at T1 (Blishen et al., 1987)

Work orientations: $\mathrm{T} 1$ responses on a five-point Likert scale ( $1=$ not at all important, $5=$ very important) to two standard work value items (source: Quinn \& Stains, 1979; Burstein et al., 1975) regarding the importance of finding "work that pays well" after leaving school, and finding "work with good chances for promotion and advancement" after leaving school; T1 responses on a five-point Likert scale ( $1=$ strongly disagree, $5=$ strongly agree) to statements tapping work commitment: "I am ready for a long-term job commitment" (source: Burstein et al., 1975) and "Having a job makes me feel I'm doing something useful with my life" (source: Jackson et al., 1983). The four work value and commitment items are used separately because of their low inter-correlation (alpha=.07).

\section{Structural}

Occupational gender segregation index: To capture the influence of the gender-segregated structure of the labour market that graduates entered on their initial employment outcomes, we created an occupational gender segregation index. This measures the percentage of women in a respondent's T2 occupation in the Canadian labour force in 1986, using a 21 category occupational classification scheme (Statistics Canada, 1986, p. 105).

Labour market experience: Employed at any time during last year of university ( $1=y e s)$; participated in a government job 
creation program during the year after graduation ( $1=y e s)$; number of weeks in current job; actual hours usually worked per week.

Job characteristics: Three independent variables tap respondents' descriptions of the extrinsic characteristics of their current job (good promotion opportunities [included only in equation predicting income], good fringe benefits, good job security). We also constructed a scale (alpha $=.85$ ) incorporating four intrinsic job characteristics (interesting work, freedom to make decisions, job gives a feeling of accomplishment, job allows use of respondent's skills and abilities). Individual items were rated on a five-point Likert scale (1=strongly agree, $5=$ strongly disagree) and the intrinsic scale score is the sum of the four component items, to a maximum of 20. (Source for all extrinsic and intrinsic items: Quinn \& Staines, 1979.) Union membership and professional association membership were also measured (for both $1=y e s$ ).

The two dependent variables are:

a) The natural log of net weekly take-home pay.

b) Respondent's description of her or his current job as offering good chances for promotion (rated on a five-point Likert scale with $1=$ strongly agree and $5=$ strongly disagree).

We should note that the equation for income included the promotion opportunities measure as a predictor, on the assumption that promotion opportunities are a basic feature of internal labour markets. As such, advancement opportunities may be part of a larger package of desirable job conditions which affect the income of men and women differently.

Table 4 examines the net effects of the above independent variables on average weekly take-home pay one year after graduation. Looking at females first, we can account for $25 \%$ of the variation in net earnings. Females who belonged to a union or professional association, graduated from an Education faculty, had a job with good fringe benefits, and had employment experience before graduating had significantly higher net pay. Conversely, participation in a government-sponsored job creation program during the year following graduation, and living in Toronto, are weakly associated with lower earnings.

In contrast, none of these factors has a significant net impact on male earnings. Clearly, males benefit from occupational gender segregation, given that this is the only significant predictor of earnings, alone accounting for $13 \%$ of 
Table 4

Reduced-form Regression Equations Predicting Income ${ }^{1}$ for Males and

Females Employed Full-time One Year After Graduation ${ }^{2}$

Female

Male

\section{Dependent Variable}

Log of average weekly take-home pay in job held one year after graduation

\section{Independent Variables}

Toronto sub-sample

(dummy variable: Toronto $=1$ )

$-.125^{\circ}$

Education faculty

(.031)

(dummy variable: Education faculty $=1$ )

$.149^{*}$

Percent female in occupation, 1986

Canadian labour force

Work experience before graduation (yes $=1$ )

$(.000)$

Employed in government job program

in year after graduation (yes $=1$ )

Number of weeks in job

Job has good fringe benefits

(five-point Likert scale, 5=strongly agree)

Union member (yes $=1$ )

Professional association member $($ yes $=1$ )

Constant

Adjusted R Square

$* \mathrm{p}<.05 \quad{ }^{* *} \mathrm{p}<.01 \quad{ }^{* * *} \mathrm{p}<.001$

1 Reduced-form regression equations include only those independent variables which had significant $(p<.05)$ net effects in stepwise regression equations using all independent variables. Pairwise deletion of missing data. Standardized regression coefficients are reported (standard errors shown in parentheses).

2 Includes only those respondents who reported holding a full-time job at the time of the 1985 followup survey $(\mathrm{n}=529)$. 
Table 5

Reduced-form Regression Equations Predicting Promotion, ${ }^{1}$ for Males and

Females Employed Full-time One Year After Graduation Opportunities ${ }^{2}$

Female

Male

\section{Dependent Variable}

Promotion opportunities in job held one year after graduation

\section{Independent Variables}

Engineering faculty

(dummy variable: Engineering faculty $=1$ )

Business faculty

(dummy variable: Business faculty $=1$ )

Mean hours usually worked per week

Job security is good

(five-point Likert scale, 5=strongly agree)

Intrinsic job content

(four item scale, maximum score $=20$ )

Not ready for a long-term job commitment

\section{Constant}

1 Reduced-form regression equations include only those independent variables which had significant $(\mathrm{p}<.05)$ net effects in stepwise regression equations using all independent variables. Pairwise deletion of missing data. Standardized regression coefficients are reported (standard errors shown in parentheses).

2 Includes only those respondents who reported holding a full-time job at the time of the 1985 followup survey $(\mathrm{n}=529)$.

3 The dependent variable is measured on a live-point Likert scale where $1=$ "strongly disagree" and 5="strongly agree." Respondents were asked to agree or disagree with the following description of their present job: "The chances for promotion are good." 
the total variation. In other words, entering male-dominated occupations is strongly associated (beta of -.44) with higher earnings among male graduates, regardless of their faculty or membership in a union or professional association.

In Table 5 we also discover divergent patterns when promotion opportunities at T2 are regressed on the same set of independent variables. Females who graduated from a Business faculty, placed an importance on finding a job with good chances for promotion after graduating, had a secure job, and reported good intrinsic job content tended also to have significantly better promotion opportunities. These four variables account for $20 \%$ of the variation in promotion opportunities among females.

Among males, $38 \%$ of the variation in promotion opportunities is accounted for by seven variables. The four variables, just noted, that influence female promotion opportunities also had significant net effects for males. In addition, feeling ready for a long-term job commitment, graduating from an Engineering faculty, and working longer than average hours weekly were positively associated with good promotion opportunities.

\section{Discussion}

To recap, we have documented that male and female university graduates have comparable socio-demographic characteristics, final year grades, student work experiences, and basic work attitudes; however, women are concentrated in traditional areas of study (Education and Arts faculties), have lower occupational aspirations, and place less importance on obtaining a job with good opportunities for promotions and advancement.

While our focus on three universities is appropriate for addressing questions about gender differences in the transition to full-time employment, some caution must be exercised in generalizing these findings. Although we found no city effect (a proxy for university attended), Anisef's (1982) study of graduates from Ontario universities in 1977-1979 showed that type of university attended directly influenced initial occupational attainment, especially for women. A more systematic exploration of specific micro and macro factors which create "gendered" transitions to employment for graduates from different types of universities is not possible, however, using existing large-scale data sets (e.g., the National Graduates Survey), because of their narrower human capital focus.

We have shown that the transition from university to full-time employment reinforces existing patterns of gender inequality. This partly is due to gender-specific patterns regarding field of study, as other researchers have also documented (Wannell, 1990). Yet similar human capital endowments, such as a specific degree, are developed differently for men and women early in their 
careers. Even after faculty effects are controlled for, there remain variations in earnings and promotion opportunities due to gender-segregated occupational structures, union and professional association membership, and other specific job conditions. In short, men and women graduating from the same faculty and university translate credentials into different kinds of employment futures.

Our goal has been to show that different combinations of socio-demographic, educational, work attitude, and labour market factors affect the initial careers of men and women in the same cohort of university graduates. We can now conclude that the conversion of human capital into pay or promotion opportunities occurs differently for men and women. In terms of earnings, what seems to matter for women, but not men, is having chosen a faculty, such as Education, with a direct channel into a specific professional labour market. As is clear from the case of female Education graduates, entering an occupation where a union or professional association has bargained for higher wages is also important. This effect of labour market bargaining power is net of any faculty effects, suggesting that one obvious way for women, regardless of their education, to improve their earnings is by joining such organizations. Similarly, work experience while in university appears to confer later labour market advantages for women. To what extent employers place more emphasis on this trait when recruiting female (but not male) graduates is an issue that will have to await further research.

Perhaps the most striking result from our multivariate analysis of earnings determinants concerns occupational gender-segregation. This structural factor is widely acknowledged as a major impediment to gender equality in employment opportunities and rewards. While entering occupations with low proportions of women seems to have little impact on female earnings, the sex ratio of entrylevel jobs is the single most important determinant of male earnings. There are obvious policy implications flowing from this finding. Men will continue to benefit economically from the present gender structure of occupations until pay equity and employment equity policies succeed in dismantling it. So far, legislation has had limited success moving in this direction (see Canada, 1992).

In terms of promotion opportunities, we found greater similarities between men and women. Our finding that men are more concerned with "getting ahead" in a job is consistent with other studies (Purcell, 1989, p. 159; Dex, 1988, p. 54); however, multivariate analysis found it to be a significant factor in the career choices of both sexes. Wanting a job with good chances for advancement at the time of graduation increased the probability of getting such a job within a year of graduating, regardless of sex. 
More broadly, labour market structure - measured by the degree of male/female segregation within occupations nationally - accentuates the impact of prior gender socialization on work orientations. Thus, women with what traditionally have been labelled "male" orientations are, in comparison with their peers, more likely to enter career paths with greater chances for mobility. Future studies could usefully address how much of this orientation to career mobility is due to the effects of specific programs of study. But we do know, given our longitudinal design, that these attitudinal differences are not a product of initial employment experiences.

The sorting of individuals into entry-level jobs contributes to the perpetuation of gender-segregated labour markets and the resulting inequalities in job rewards (Blossfeld, 1987). In broader theoretical terms, this process requires researchers to revise structural models of employment to incorporate individual characteristics. Beyond this, it is important to focus on major life transitions, such as from university into the labour market, to document how individuals move through social institutions into adult life. A creative integration of micro and macro perspectives thus promises to enhance our understanding of gender inequalities in education and employment.

\section{Notes}

1 This revised scale is a composite index, based on average income and education levels in over 500 occupations, using 1981 Census data. We acknowledge that the Blishen Scale is unable to capture fully the underlying structure of gender-based occupational inequalities (Fox \& Suschnigg, 1989). The scale is useful, however, for our limited purpose of measuring gender differences in occupational aspirations. If anything, the scale probably understates these discrepancies.

2 By comparison, examples of occupations at the opposite ends of the scale are newspaper carriers and vendors (score of 18) and physicians and surgeons (score of 101). To make the scores in Table 2 more concrete, we should note that elementary teachers score 63 and mechanical engineers score 68.

3 We did not use a forced entry procedure. Rather, letting the SPSSX program enter the independent variables in the order of their impact on the dependent variable allows us to identify precisely which variables are important for each gender. This approach is justified, given that we are not attempting to "test" a theory, strictly speaking. Instead, we want to explore the heuristic value of combing structural and individual factors into a fuller explanation. 


\section{References}

Anisef, P. (1982). University graduates revisited: Occupational mobility attainments and accessibility. Interchange, 13, 1-19.

Baron, J. N. \& Bielby, W. T. (1980). Bringing the firms back in: Stratification, segmentation, and the organization of work. American Sociological Review, 45, 737-765.

Beechey, V. (1988). Rethinking the definition of work. In J. Jenson, E. Hagen, \& C. Reddy (Eds.), Feminization of the labour force: Paradoxes and promises. New York: Oxford University Press.

Becker, G. (1985). Human capital, effort and the sexual division of labour. Journal of Labour Economics, 3, S33-S58.

Blishen, B., Carroll, W., \& Moore, C. (1987). The 1981 socio-economic index for occupations in Canada. Canadian Review of Sociology \& Anthropology, 24, 456-488.

Blossfeld, H. (1987). Labour market entry and the sexual segregation of careers in the Federal Republic of Germany. American Journal of Sociology, 93, 89-118.

Brinton, M.C. (1988). The social-institutional bases of gender stratification: Japan as an illustrative casc. American Journal of Sociology, 94, 300-334.

Burstein. M., et al. (1975). Canadian work values: Findings of a work ethic survey and a job satisfaction survey. Ottawa: Manpower \& Immigration.

Canada. (1992) A matter of fairness. Report of the special committee on the review of the Employment Equity Act. Ottawa: House of Commons.

Coverman, S. (1988). Sociological explanations of the male-female wage gap: Individual and structuralist theorics. In A. Helton Stromberg \& S. Harkness (Eds.), Working women: Theories and facts in perspective, 2nd edition. Mountainview, CA: Mayticld.

Devereaux, M.S., \& Rechnitzer, E. (1978). Higher education - Hired? Ottawa: Statistics Canada.

Dex, S. (1985). The sexual division of work. Brighton: Wheatsheaf Books.

Dex, S. (1988). Women's attitudes towards work. London: Macmillan.

Fox, J. \& Suschnigg, C. (1989). A note on gender and the prestige of occupations. Canadian Journal of Sociology, 14, 353-360.

Gaskell, J. (1987). Education and the labour market: The logic of vocationalism. In T. Wotherspoon (Ed.), The political economy of Canadian schooling. Toronto: Methuen.

Gilbert, S. \& Guppy, N. (1988). Trends in participation in higher education by gender. In J. Curtis, E. Grabb, N. Guppy, \& S. Gilbert (Eds.), Social inequality in Canada: Patterns, problems, policies. Scarborough: Prentice-Hall.

Gunderson, M. (1989). Male-female wage differentials and policy responses. Journal of Economic Literature, 27, 46-72

Harvey, E.B. \& Kalwa, R. (1983). Occupational status attainment of university graduates: Individual attributes and labour market effects. Canadian Review of Sociology \& Anthropology, 12, 435-453.

Ireson, C. \& Gill, S. (1988). Girl's socialization for work. In A. Helton Strombery \& S. Harkness (Eds.), Working women: Theories and facts in perspective, 2 nd edition. Mountainview, CA: Mayficld. 
Jackson, P.R., Stafford, E.M., Banks, M.H., \& Warr, P.B. (1983). Unemployment and psychological distress in young people: The moderating role of employment commitment. Journal of Applied Psychology, 68, 525-535.

Jacobs, J.A. (1989). Long-term trends in occupational segregation by sex. American Journal of Sociology, 95, 160-173.

Kalleberg, A. \& Berg, I. (1987). Work and industry: Structures, markets, and processes. New York: Plenum.

Knottnerus, D.J. (1987). Status attainment research and its image of society. American Sociological Review, 52, 113-121.

Krahn, H. (1988). A study of the transition from school to work in three Canadian cities: Research design, response rates and descriptive results. Edmonton: Population Research Laboratory, University of Alberta.

Krahn, H. \& Lowe, G.S. (1993). Work, industry and Canadian society. Scarborough: Nelson Canada.

Krahn, H. \& Lowe, G.S. (1990). Young workers in the service economy, Working paper No. 14. Ottawa: Economic Council of Canada.

Lorence, J. (1987). A test of "gender" and "job" models of sex differences in job involvement. Social Forces, 66, 121-142.

MacKie, M. (1987). Constructing women and men: Gender socialization. Toronto: Holt, Rinchart and Winston.

Marshall, K. (1989). Women in professional occupations: Progress in the 1980s. Canadian Social Trends, Spring, 13-16.

Moen, P. \& Smith, K.R. (1986). Women, work commitment and behaviour over the life coursc. Sociological Forum, 1, 450-475.

Mori, G.A., \& Burke, B. (1989). Educational attainment of Canadians. Ottawa: Supply and Services.

Peitchinis, S.G. (1989). Women at work: Discrimination and response. Toronto: McClelland \& Stewart.

Porter, J., Porter, M., \& Blishen, B. (1982). Stations and callings: Making it through the school system. Toronto: Methuen.

Purcell, Kate. (1989). Gender and the experience of employment. In D. Gallie (Ed.), Employment in Britain. Oxford: Basil Blackwell.

Quinn, R.P. \& Stains, G.L. (1979). The 1977 quality of employment survey. Ann Arbor, Michigan: Survey Research Center, Institute for Social Research, University of Michigan.

Statistics Canada. (1986). The labour force. December [catalogue \#71-001].

Turrittin, A.H., Anisef, P., \& MacKinnon, N.J. (1983). Gender differences in educational achievement: A study of social inequality. Canadian Journal of Sociology, 8, 395419.

Wannell, T. (1990). Male-female carnings gap among recent university graduates. Perspectives on Labour and Income, Summer, 19-31. 